\title{
BIOECOLOGY OF THE UÇÁ-CRAB, Ucides cordatus (LINNAEUS, 1763), IN VITÓRIA BAY, ESPÍRITO SANTO STATE, BRAZIL
}

\author{
Péricles Goes ${ }^{I}$; Joaquim Olinto Branco ${ }^{2}$; Marcelo Antonio Amaro Pinheiro ${ }^{3}$; Edison Barbieri ${ }^{4}$; Dulcileia Costa \\ and Luiz Loureiro Fernandes ${ }^{l}$. \\ ${ }^{1}$ Universidade Federal do Espírito Santo, Departamento de Ecologia e Recursos Naturais \\ (Avenida Fernando Ferrari, s/n, 29060-900 Vitória, ES, Brasil) \\ e-mail: coluthgoes@yahoo.com.br \\ ${ }^{2}$ Universidade do Vale do Itajaí - Centro de Ciências Tecnológicas da Terra e do Mar \\ (Caixa Postal 360, 88301-970 Itajaí, SC, Brasil) \\ e-mail:branco@univali.br \\ ${ }^{3}$ Universidade Estadual Paulista - UNESP \\ Campus Experimental do Litoral Paulista (CLP), Grupo de Pesquisa em Biologia de Crustáceos (CRUSTA) \\ (Praça Infante Dom Henrique, s/n, 11330-900 São Vicente, SP, Brasil) \\ e-mail: pinheiro@clp.unesp.br \\ ${ }^{4}$ Instituto de Pesca (Apta - SAA/SP) \\ (Av. Prof. Besnard s/n, 11990-000 Cananéia, SP, Brasil) \\ e-mail: edisonbarbieri@yahoo.com.br
}

\begin{abstract}
A B S TR ACT
The biology of the Ucides cordatus in Vitória Bay (ES) was evaluated as a possible tool for population management. Sampling occurred monthly for about a year (October 1998 to September 1999) with biometric analysis (CW = carapace width; $\mathrm{WW}=$ total wet weight) and abiotic factors on four transects, each with four bands (margin to supratidal region). The density was $3.7 \pm 1.5 \mathrm{crabs} . \mathrm{m}^{-2}$, with an increase toward the supratidal region, and depth of the galleries with $1.1 \pm 0.3 \mathrm{~m}$. The salinity of interstitial water differed between bands, being higher in the supratidal. There was significant correlation between the abundance of individuals and some environmental factors, the same occurring with open and closed burrows. The sex ratio showed a predominance of females (1.0M:1.6F), particularly between 50 and $75 \mathrm{~mm}(\mathrm{CW})$. The higher incidence of closed burrows occurred in August and September, while ovigerous females were recorded from January to April. The relationship WW/CW showed isometry for males (WW=0,425.10 $0^{-3} \mathrm{LC}^{3,0014} ; \mathrm{R}^{2}=0.99$ ) and females (WW $\left.=0,439.10^{-3} \mathrm{LC}^{2,97} ; \mathrm{R}^{2}=0.99\right)$. For the total population the average size $(\mathrm{CW})$ and weight $(\mathrm{WW})$ were $54.6 \pm 11.8 \mathrm{~mm}$ and $77.5 \pm 42.4 \mathrm{~g}$, respectively. The population is under super-exploitation, requiring proper management for the viability of activity in the area.
\end{abstract}

\section{RESUMO}

A biologia de Ucides cordatus na Baía de Vitória (ES) foi avaliada como subsídio ao manejo populacional. As amostragens ocorreram mensalmente durante um ano (outubro/1998 a setembro/1999), com análise biométrica ( $\mathrm{LC}=$ largura da carapaça; $\mathrm{PE}=$ peso total úmido) e de fatores abióticos em quatro transectos, com quatro faixas cada (margem à região supratidal). A densidade foi de $3,7 \pm 1,5$ caranguejos. $\mathrm{m}^{-2}$, com incremento em direção à região supratidal, sendo a

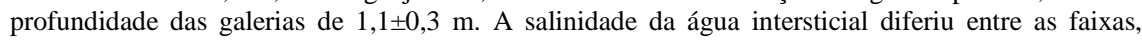
sendo mais elevada na região supratidal. Houve correlação significativa entre a abundância de exemplares e alguns fatores ambientais, o mesmo ocorrendo quanto as tocas abertas e fechadas. A razão sexual evidenciou um predomínio de fêmeas $(1,0 \mathrm{M}: 1,6 \mathrm{~F})$, particularmente entre 50 e $75 \mathrm{~mm}$ LC. A maior incidência de tocas fechadas ocorreu em agosto e setembro, enquanto as fêmeas ovígeras foram registradas de janeiro a abril. A relação PE/LC mostrou isometria para os machos $\left(\mathrm{PE}=0,425 \cdot 10^{-3} \mathrm{LC}^{3,0014} ; \mathrm{R}^{2}=0,99\right)$ e fêmeas $\left(\mathrm{P}=0,439.10^{-3} \mathrm{LC}^{2,97} ; \mathrm{R}^{2}=0,99\right)$. Para o total da população a média de tamanho (LC) e peso (PE) foi de $54,6 \pm 11,8 \mathrm{~mm}$ e de $77,5 \pm 42,4 \mathrm{~g}$, respectivamente. Os dados evidenciam que a população encontra-se sobrexplotada, requerendo manejo adequado para a viabilidade da atividade extrativa na área estudada.

Descriptors: Burrows, Density, Mangrove, Sex ratio, Weight.

Descritores: Densidade, Razão sexual, Peso, Manguezal. 


\section{INTRODUCTION}

The mangrove crab Ucides cordatus (Linnaeus, 1763) is a species of economic interest with wide geographical distribution on the Atlantic coast, occurring from Florida to Santa Catarina (BR) (MELO, 1996). In mangrove forest, the adult crabs mainly inhabit the intertidal area, where they dig their burrows and pneumatophores among the roots, to depths of 0.6 to $2.0 \mathrm{~m}$ (COSTA, 1979; NASCIMENTO, 1993; BRANCO, 1993; DIELE, 2000; PINHEIRO; FISCARELLI, 2001), while their young are more often found at the edges of the mangrove swamps/forests (COSTA, 1979).

Until as late as 1998 our knowledge of the biology and ecology of $U$. cordatus was still sparse, with a subsequent increase, however, due to important projects conducted by some research groups in Brazil, among which were the Madam Project (Bragança, PA), the Caranguejo Project (Vitória, ES) and the Uçá Project (Iguape, SP), in addition to other academic and scientific contributions. The action of IBAMA (more recently undertaken by ICM-Bio) was decisive for the advance in our knowledge of the biology of this species due to the state-of-the-art publication some years later by IBAMA (1994). This publication revealed a previous lack of information with a greater refinement of the biology of $U$. cordatus, necessary for the final elaboration of the fishery laws that resulted in the agreements made with a view to the participatory management which occurred in some Brazilian regions, especially in the south-southeast (RODRIGUES et al., 2000), that, in its turn, led to the current law published by IBAMA (2003) - IBAMA n ${ }^{\circ}$ $52 / 2003$. Several developments have, since then, become evident in the literature (see review by CASTILHO-WESTPHAL et al., 2008), particularly as regards growth in size and weight (PINHEIRO et al., 2005; PINHEIRO; HATTORI, 2006; PINHEIRO; FISCARELLI, 2009), size at the onset of maturity (PINHEIRO, 2004; DALABONA et al., 2005), population structure, density and habitat partition (DIELE et al., 2005; HATTORI, 2006), distribution (OLIVEIRA, 2005), trophic ecology (WOLFF et al., 2000; CHRISTOFOLETTI, 2005; NORDHAUS et al., 2006; NORDHAUS; WOLFF, 2007) and extractive potential (FERNANDES; CARVALHO, 2007; WUNDERLICH et al., 2008; ARAÚJO; CALADO, 2008), indicating the urgent need of a population management policy, particularly after the classification of $U$. cordatus as an overexploited species by MMA law $n^{\circ}$ 5/2004 (MMA, 2004). In this sense, from mid2008, several meetings have been held by the Brazilian Ministry of the Environment (MMA), focused on the preparation of the National Management Program relating to Ucides cordatus and two other brachyuran species (Cardisoma guanhumi-
"Guaiamú"; and Callinectes sapidus - "Siri Azul") to be published in the near future.

In recent years, crab captures have decreased in several Brazilian states and this has been seen as the first sign of the overexploitation of $U$. cordatus population stocks (ARAÚJO, 2006), mainly in some northeast states (Rio Grande do Norte, Paraiba, Pernambuco, Alagoas, Sergipe and northern Bahia). In these mangrove areas the disregard for fishery protection regulations or their absence has substantially changed the population structure of the species, leading to a reduction of the legal weight and capture size (LEGAT; PUCHNICK, 2003) and promoting a sex ratio imbalance (DIELE et al., 2005). Specifically on the coast of Espírito Santo State, the pressure that the crab collectors have exercised on the stocks over the years has been reported since the 80's (CARMO, 1987), and it has led to reduction in the average size of the individuals, mainly the males, in the mangrove swamps/forests of Vitória Bay (GOES et al., 2000). According to Vale (1994), the crab collectors use this species both for their own consumption and for sale, which can often cause significant anthropogenic impact on the mangrove forest.

This study aims to evaluate some aspects of the biology of $U$. cordatus, especially its abundance, sex ratio, weight/carapace width, as well as the influence of some environmental variables on the population density of this species in the mangrove forests of Vitória Bay, Brazil.

\section{MATERIAL AND METHODS}

The mangrove forests of Vitória Bay occupy an area of approximately $18 \mathrm{~km}^{2}$. This study was undertaken in the northeastern portion of the bay $\left(20^{\circ} 14^{\prime} 20^{\prime}\right.$ 'S $\left.-40^{\circ} 18^{\prime} 30^{\prime \prime} \mathrm{W}\right)$, in a mangrove forest composed of four arboreal species: Rhizophora mangle Linnaeus, Laguncularia racemosa C. F. Gaertn, Avicennia schaueriana Stapf \& Leechman and Avicennia germinans Linnaeus. The mangrove area studied has undergone great anthropic pressure due to the proximity of Vitória (a city of approximately 320,000 people, according to IBGE, 2009), the capital of Espírito Santo State and bathed by the waters of the Carapina channel (CARMO et al., 1995).

The sampling was carried out monthly, during low tide, in the daytime, over three to four days per month, from October 1998 to September 1999. Four equidistant transects were established (100m apart), each of about $200 \mathrm{~m}$ in length, from the bank of the channel to the supratidal region. Four portions (bands) were sampled monthly by transect, corresponding to 050m (Band I), 50-100 m (Band II), 100-150 m (Band III) and 150 m-hipersaline plain (Band IV). 
Each gallery was inspected manually to detect any intercommunication with other gallery ducts, taking only one gallery into consideration at a time when it occurred (COSTA, 1979; HATTORI, 2006). Each gallery was evaluated in the light of its external morphology and classified as open or closed (SANTOS et al., 2009). The total number of galleries per square meter was counted and used to estimate the crab density in each band, delimited with two nylon strips (marked in meters), tied to wooden stakes, and extended parallel to the transect at a distance of one meter (BRANCO, 1993).

Water samples were obtained monthly with four PVC collectors previously installed, to register the interstitial salinity, $\mathrm{pH}$ and temperature. Sediment and air temperatures were also registered, as well as the interstitial salinity of the sediment and the salinity of the water inside the open galleries. Samples of the sediment in each band were collected using an adapted collector for mangrove forests (REBELO-MOCHEL, 1986) and submitted to granulometric analysis to obtain four fractions: sand (coarse and fine), silt and clay.

The depth of the galleries was estimated using a $2.5 \mathrm{~m}$ length of cotton twine $(3.0 \mathrm{~mm}$ diameter) that was tied to the base of the minor cheliped of each specimen before its release at the opening of its gallery. The depth of the gallery was estimated by the difference between the total length of the cotton twine and that recorded at the entrance to the gallery, once the specimen had reached the bottom of the same.

The sex of the specimens established by inspection, in the laboratory, of the abdominal morphology and the number of pleopods (see PINHEIRO; FISCARELLI, 2001), their measurement with calipers $(\mathrm{CW}=$ maximum cephalothorax width, in millimeters) and weighing with a digital electronic balance $(\mathrm{WW}=$ total wet weight, in grams), were registered.

The ANOVA (ZAR, 1999) was applied for each environmental parameter registered in the bands sampled, and they were also tested for homogeneity (Bartlett's test) and normality of distribution (Kolmogorov-Smirnov test). The cases characterized by statistical differences were tested with the TukeyKramer test which was applied to verify possible contrast between the averages. The relationship WW/CW was evaluated for males and females, according to the procedures described by Pinheiro and Fiscarelli (2009). Pearson's correlation coefficient was used to verify the association between crab abundance and total number of burrows (open and closed) and the environmental variables studied.

Juvenile crabs ( $\mathrm{CW} \leq 40 \mathrm{~mm}$, according Goes et al., 2000), represented by juvenile males and females, were grouped for statistical analysis. The $\mathrm{X}^{2}$ test was applied to verify any possible difference between sexual proportion by month and CW distribution class (VAZZOLER, 1996).

The significance level of the statistical tests was set at 5\%, while for Pearson's correlation coefficient it was established at 5 and $1 \%$.

\section{RESULTS}

The crab density in the bands varies between 1.5 and 5.0 crabs. $\mathrm{m}^{-2}$ (Table 1), with a total average density of $3.7 \pm 1.5$ crabs. ${ }^{-2}$, which corresponds approximately to 37,000 individuals per hectare. The average number of open and closed burrows shows a tendency to increase from the border of Carapina Channel (lower mangrove band) to the hipersaline plain (upper mangrove band), with a significant predominance of closed burrows over open ones in Band IV ( $\mathrm{t}=4.14 ; \mathrm{p}<0.05 ; \mathrm{df}=35)$ (Table 1$)$.

Table 1. Crab density (crabs. $\mathrm{m}^{-2}$ ) based on open, closed and total burrows and depth of galleries (m), represented by average \pm standard deviation in each band sampled ( $\mathrm{I}=0-50 \mathrm{~m} ; \mathrm{II}=50-100 \mathrm{~m} ; \mathrm{III}=100-150 \mathrm{~m}$; and IV = 150m-hipersaline plain).

\begin{tabular}{|c|c|c|c|c|c|}
\hline \multirow[b]{2}{*}{ Band } & \multicolumn{3}{|c|}{ Density (crabs.m ${ }^{-2}$ ) } & \multirow[b]{2}{*}{ Student's t-test } & \multirow[b]{2}{*}{$\begin{array}{l}\text { Depth of the galleries } \\
(\mathrm{m})\end{array}$} \\
\hline & $\begin{array}{c}\text { Open } \\
\text { Burrows }\end{array}$ & $\begin{array}{l}\text { Closed } \\
\text { Burrows }\end{array}$ & Total & & \\
\hline I & $1.5 \pm 0.8$ & $1.5 \pm 0.9$ & $3.0 \pm 1.4$ & $\mathrm{t}=0.07 ; \mathrm{df}=46^{\mathrm{ns}}$ & $1.03 \pm 0.15$ \\
\hline II & $1.7 \pm 0.7$ & $1.5 \pm 0.8$ & $3.2 \pm 1.0$ & $\mathrm{t}=1.80 ; \mathrm{df}=42^{\mathrm{ns}}$ & $1.10 \pm 0.25$ \\
\hline III & $1.6 \pm 0.7$ & $1.8 \pm 1.1$ & $3.4 \pm 1.2$ & $\mathrm{t}=1.97 ; \mathrm{df}=36^{\mathrm{ns}}$ & $1.13 \pm 0.27$ \\
\hline IV & $1.8 \pm 1.1$ & $3.2 \pm 1.1$ & $5.0 \pm 1.5$ & $\mathrm{t}=4.14 ; \mathrm{df}=46 *$ & $1.05 \pm 0.22$ \\
\hline
\end{tabular}


Despite the significant oscillations registered over the year, the average number of total burrows (open and closed) showed no significant differences $(\mathrm{t}=1.58 ; \mathrm{p}>0.05 ; \mathrm{df}=22)$, although the highest means of closed burrows occurred mainly in August and September (Fig. 1). The depths of burrows varied between 1.03 and $1.13 \mathrm{~m}$, corresponding to an average total depth of $1.10 \pm 0.26 \mathrm{~m}$ (Tab. 1).

There was no variation between the average air temperatures of the sampled bands $\quad\left(\mathrm{F}_{3-44}=0.39\right.$; $\mathrm{p}>0.05$ ), the same occurring with those registered for the water in the burrows $\left(\mathrm{F}_{3-44}=0.09 ; \mathrm{p}>0.05\right)$ and when the monthly averages of the air and burrow water temperatures were compared $(t=1.98 ; \mathrm{p}>0.05$, $\mathrm{df}=22$ ) (Fig. 2a). Average data of the interstitial water salinity in Band IV were higher and more significant than the others $\left(\mathrm{F}_{3-44}=10.67 ; \mathrm{p}<0.01\right)$. No differences were found among the burrow water salinity values of the bands $\left(\mathrm{F}_{3-44}=1.57 ; \mathrm{p} \geq 0.05\right)$ or when the interstitial and burrow water salinity was compared $(\mathrm{t}=0.41$; $\mathrm{p} \geq 0.05$, df=22) (Fig. 2b).

Persons' correlation coefficient indicates a positive and significant association $(\mathrm{p}<0.01)$ between total crab abundance and temperature values (air, sediment and burrow water), as well as with coarse sand but a negative correlation with clay (Table 2). The total of burrows was positive and strongly associated with salinity (interstitial water and burrow water) $(\mathrm{p}<0.01)$, positive though weakly associated with $\mathrm{pH}$ and coarse sand $(\mathrm{p}<0.05)$, and negatively correlated with silt and clay $(\mathrm{p}<0.01)$. The numbers of open and closed burrows differ when correlated with environmental variables, a positive significance occurring with temperature (sediment and burrow water) and salinity (interstitial and burrow water), respectively. Bands III and IV were characterized by the highest levels of interstitial and burrow water salinities, related to a predominance of closed burrows (Tables 1 and 2).

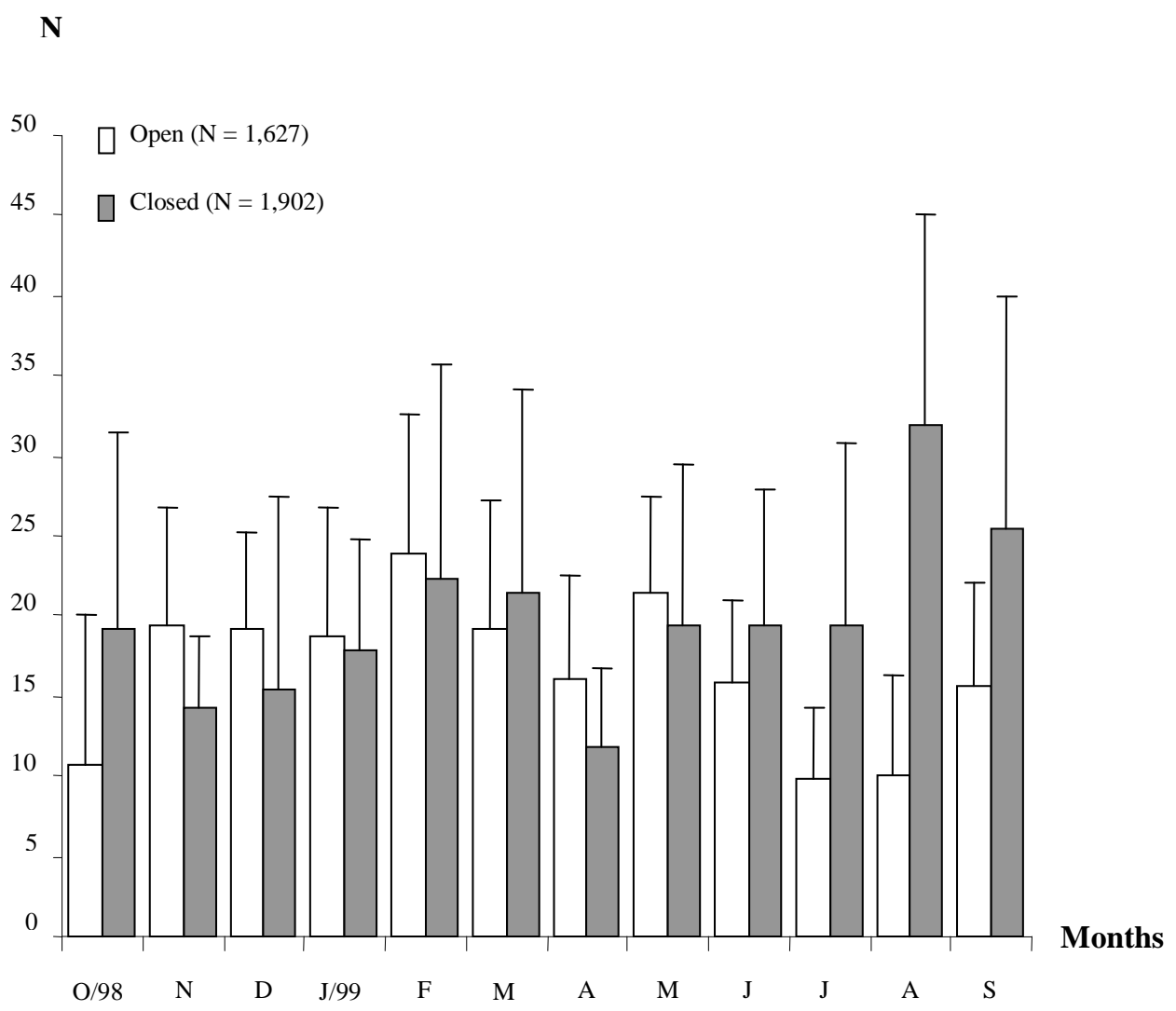

Fig. 1. Monthly variation of the average number (bars) of the open and closed burrows of Ucides cordatus (lines = standard deviation). 

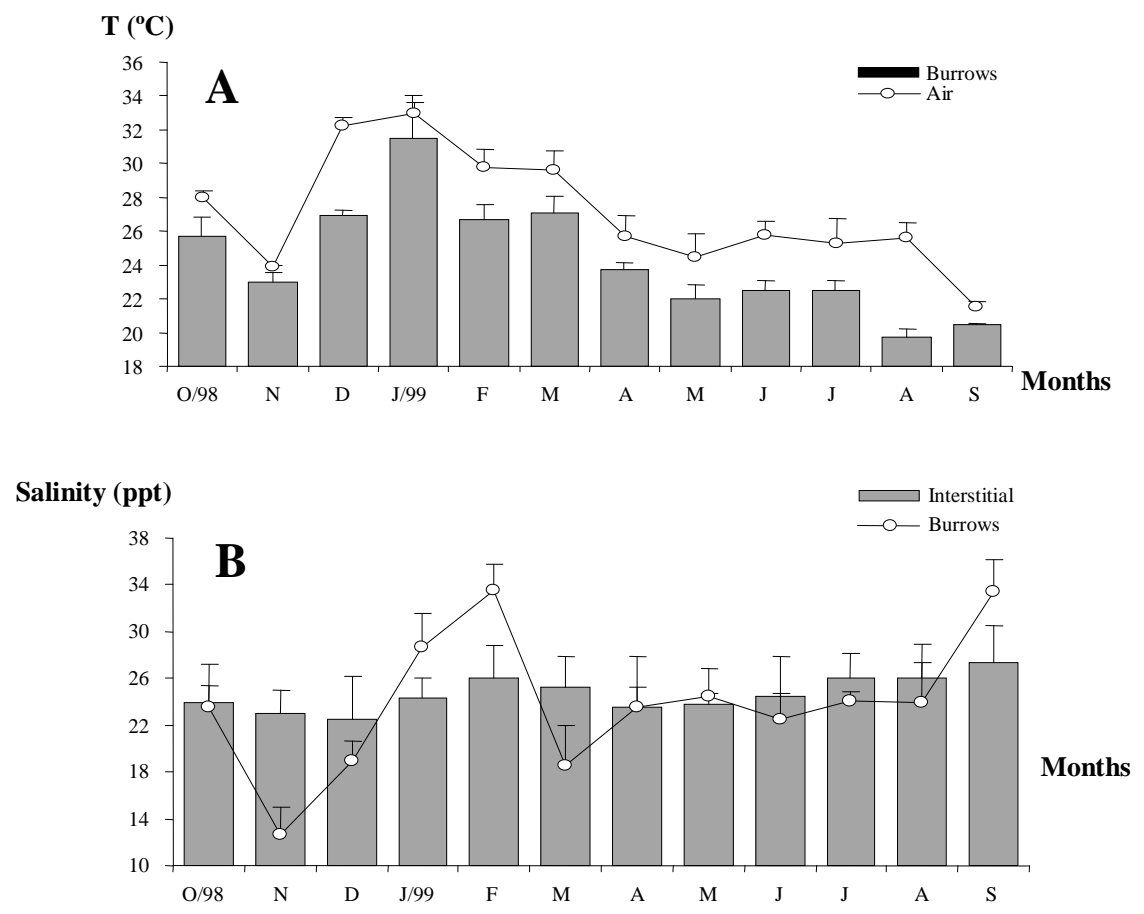

Fig. 2. Average monthly temperature of air and water of burrows (a), average levels ( \pm standard deviation) of interstitial water and open burrow salinity of Ucides cordatus.

Of the 496 crabs captured, 157 were adult males (31.8\%), 239 adult females without eggs (48.3\%), 63 juveniles (12.9\%) and 34 ovigerous (7.0\%). Total sex ratio was $1 \mathrm{M}: 1.6 \mathrm{~F}$ in the population $\left(\mathrm{X}^{2}=5.47 ; \mathrm{p}<0.05\right)$ (Fig. 2) and this tendency was greater in some of the months sampled (November,
March-May and July-September), coincidentally with a dominance of non-ovigerous females. Juveniles occurred at low frequencies along the year, while overigenous females were registered from January to March (Fig. 3).

Table 2. Pearson's correlation between each environmental variable (water, sediment and air) and total crabs, total burrows, and open/closed burrows. $*=$ significant $95 \%$; ** significant $99 \%$.

\begin{tabular}{|c|c|c|c|c|}
\hline Environmental Variables & $\begin{array}{c}\text { Total } \\
\text { Crab Abundance }\end{array}$ & Total of Burrows & Open Burrows & Closed Burrows \\
\hline Interstitial salinity & 0.09 & 0.50 ** & 0.09 & $0.58 * *$ \\
\hline Burrow water salinity & -0.03 & $0.32 * *$ & 0.08 & $0.35 * *$ \\
\hline $\mathrm{pH}$ & -0.10 & $0.21^{*}$ & 0.13 & 0.17 \\
\hline Air temperature & 0.30 ** & 0.12 & 0.18 & 0.02 \\
\hline Sediment temperature & $0.32 * *$ & -0.001 & 0.21 * & -0.15 \\
\hline Water temperature & 0.36 ** & 0.04 & $0.27 * *$ & -0.14 \\
\hline Coarse sand & 0.32 ** & 0.28 * & $\mathrm{Nt}$ & nt \\
\hline Fine sand & -0.15 & -0.05 & $\mathrm{Nt}$ & $\mathrm{nt}$ \\
\hline Silt & -0.31 & $-0.33 * *$ & $\mathrm{Nt}$ & nt \\
\hline Clay & $-0.32 * *$ & $-0.30 * *$ & $\mathrm{Nt}$ & $\mathrm{nt}$ \\
\hline Organic material & 0.10 & 0.16 & nt & $\mathrm{nt}$ \\
\hline
\end{tabular}




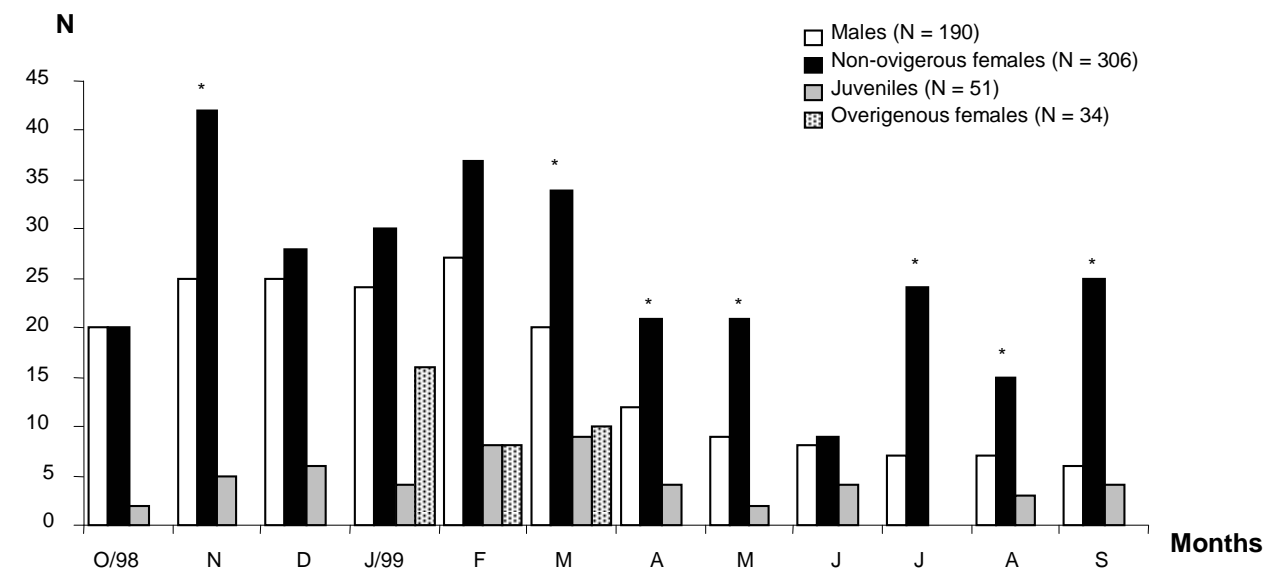

Fig. 3. Monthly distribution of Ucides cordatus abundance $(\mathrm{N})$ by morphotype $\left(* \mathrm{X}^{2}\right.$ significance, $\left.\mathrm{p}<0.05\right)$.

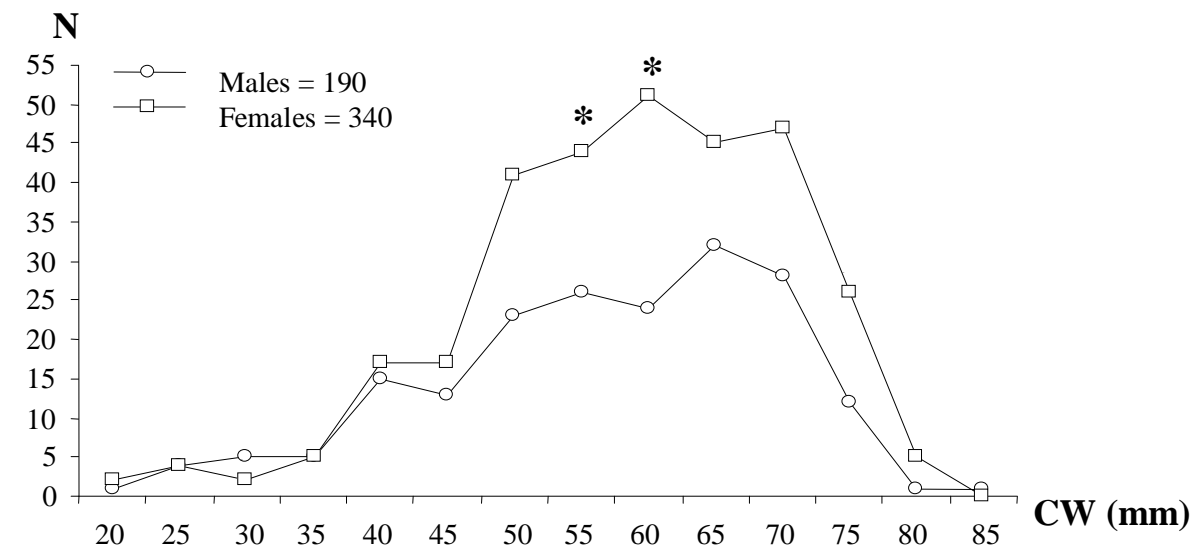

Fig. 4. Distribution of Ucides cordatus abundance $(\mathrm{N})$ by sex in each size class $(\mathrm{CW}=$ cephalothoracic width), from October 1998 to September 1999 ( $^{*} \mathrm{X}^{2}$ significance, $\left.\mathrm{p}<0.05\right)$.

The distribution of $U$. cordatus specimens by size class $(\mathrm{CW})$ revealed greater frequencies between 40 and $85 \mathrm{~mm}$ (Fig. 4), with significant female predominance in the intermediate classes $(50-75 \mathrm{~mm})$ and sexual equivalence in the other classes, except for a male predominance in $25-30 \mathrm{~mm}$. Juvenile frequencies were registered between 15 and $40 \mathrm{~mm}$.

The WW/CW ratio was isometric for males $\left(\mathrm{WW}=0.42510^{-3} \mathrm{CW}^{3.0014} ; \mathrm{R}^{2}=0.99\right)$ and females
(WW=0.439 $10^{-3} \quad \mathrm{CW}^{2.97} ; \mathrm{R}^{2}=0.99$ ) (Fig. 5), and without significance when the "b" values obtained were compared $(\mathrm{t}=0.0043 ; \mathrm{p}>0.05, \mathrm{df}=495)$. Total population has a CW variation from 17 to $85 \mathrm{~mm}$ $(54.6 \pm 11.8 \mathrm{~mm})$ and WW oscillates from 2.0 to $206.7 \mathrm{~g}$ $(77.5 \pm 42.4 \mathrm{~g})$, resulting in a common $\mathrm{WW} / \mathrm{CW}$ equation represented by $\mathrm{WW}=0.444 \quad 10^{-3} \quad \mathrm{CW}^{2.98}$ $\left(\mathrm{R}^{2}=0.99\right)$, which also followed an isometric tendency. 
WW(g)

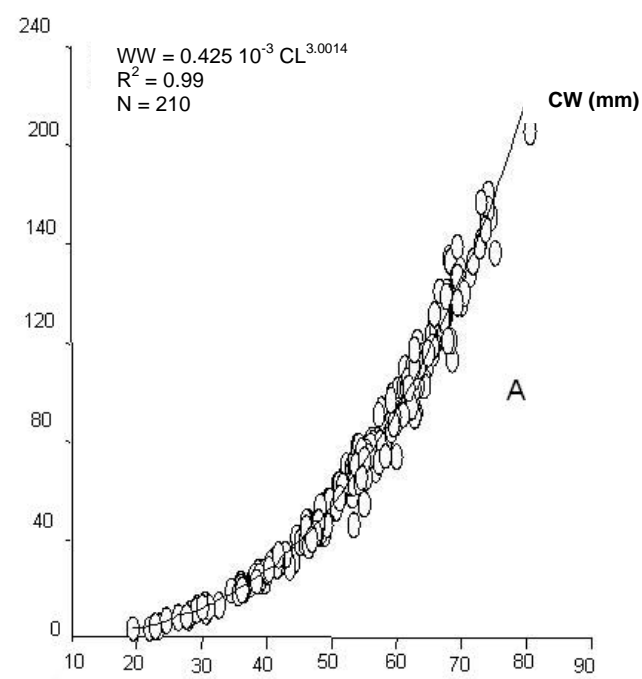

$\mathrm{WW}(\mathrm{g})$

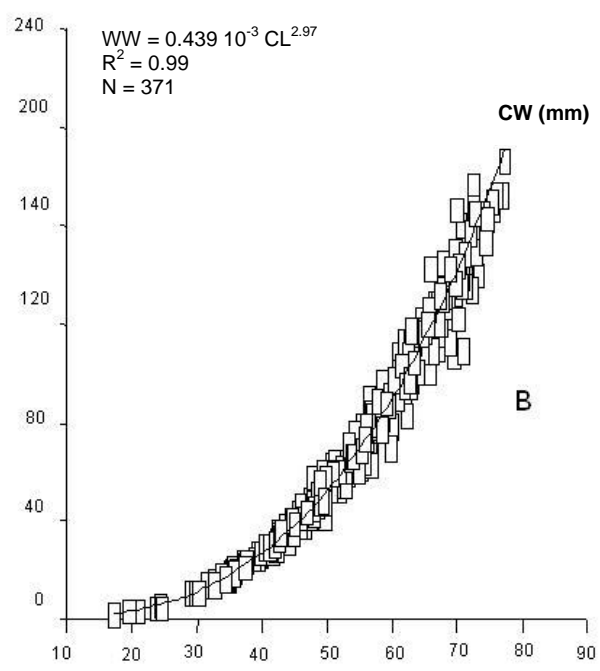

Fig. 5. Dispersion of the empirical points of the WW/CW relationship, for males (A) and females (B) (WW = total wet weight; $\mathrm{CW}=$ cephalothoracic width).

\section{Discussion}

The mean densities of open and closed burrows in the mangrove forest of Vitória Bay show an increasing tendency from the channel to the hipersaline plain. This aspect was observed mainly in Band IV, with a greater density than in other areas due to the predominance of juvenile crab burrows. These results agree with data presented by Warner (1969) for Jamaican mangrove swamps, where density oscillates from 0.2 crabs. $^{-2}$ (lower mangrove band) to 1.5 crabs. $\mathrm{m}^{-2}$ (upper mangrove band). A similar pattern occurs in Brazil, although the magnitude of the density of the presence of $U$. cordatus in mangrove areas is different, ranging from $1.1 \mathrm{crabs}^{-2} \mathrm{~m}^{-2}$ in the southern region (BRANCO, 1993) to $4.8 \mathrm{crabs}^{-2}$ in the northeast (ALCANTARA-FILHO, 1978). The occurrence of higher crab densities in upper mangrove bands has also been reported in northeastern (NASCIMENTO; COSTA, 1983), southeastern (HATTORI, 2006) and southern Brazil (BLANKENSTEYN et al., 1997), and is possibly to be explained as due to peculiar physical factors such as water level, sediment drainage, and soil humidity/salinity (ALVES; NISHIDA, 2004; HATTORI, 2006). However, despite the high density of $U$. cordatus in upper mangrove bands, the population structure in these areas indicates that it is composed of smaller individuals than those typically present in lower mangrove bands (HATTORI, 2006). Population density estimates of semiterrestrial crabs based on burrow counts tends to overestimate the density if no care is taken to discard the number of unoccupied galleries or consider those with multiple openings as single ones (MACINTOSH, 1988; MACIA et al., 2001).

The denser vegetal covering near the channel (Band I) explains the lower average temperature than that observed in the upper mangrove area (Band IV) where the vegetal covering was less dense (CARMO et al., 1995). Temperature can be used as an important indicator of crab behavior, can explain their low mobility and smaller captures in the winter months than in the summer when they are more active (GOES et al., 2000). The low winter temperatures also affect the gallery-closing behavior of the crabs, which use this period to perform the ecdysis inside and determine the period of change of the species. This study confirms the data obtained by Pinheiro and Fiscarelli $\mathrm{h}(2001)$ and Wunderlich et al. (2008), who reported a igher occurrence of closed burrows between August and September and from June to October, respectively. Nascimento (1993) cited a higher frequency of molting in the northeastern region of Brazil (Sergipe State) from September to November, while in Ceará State the greatest occurrence was detected in December (ALCÂNTARA-FILHO, 1978). Differences between periods may occur between mangrove areas by virtue of contrasts in latitude and vegetation, an interesting aspect which calls for further analysis.

Higher salinity values were registered in upper mangrove areas (Band IV) where there was less frequent flooding and greater exposure to the sun's 
heat due to the sparser vegetal covering. However, more uniform levels of water salinity are to be found inside the closed burrows (see interstitial salinity values) than in the open ones that are more subject to the influence of tides and rainfall. The positive association detected between interstitial water salinity and number of closed burrows (see Band IV) is probably related to the highest occurrence of small specimens, very common in upper mangrove areas (COSTA, 1979; NASCIMENTO, 1993; DIELE, 2000). Hattori (2006) reports a positive association between the salinity values of burrow water and the density of $U$. cordatus, an association which also holds true of the levels of calcium and magnesium, the minerals that are essential to crustaceans during the period of the hardening of their exoskeletons, in burrow water (PRATOOMCHAT et al., 2002; WHEATLY et al., 2002; ZIEGLER, 2002).

Silt and clay content directly affect the porosity, hardness and water content of sediments (BROWN; MCLACHLAN, 1994) as well as the bioturbation caused by benthic animals with scavenging habit, such as crabs (KRISTENSEN, 2008; PENHA-LOPES et al., 2009). The significant negative association between the total number of galleries and the silt and clay found in this study was similar to that reported by Hattori (2006), although the latter author has made use of density as the dependent variable, with no statistical significance. Sediments with finer particle size are easier to dig for crabs, but provide less stable galleries, thus explaining the association of these constructions by $U$. cordatus with the structural support afforded by the mangrove vegetation, particularly by its roots and branches, increasing the galleries' stability (OLIVEIRA, 2005). In this regard, the association between particle size, rooting and flooding in mangroves may also influence the scavenging depth of Ucides cordatus, reaching more than $2 \mathrm{~m}$ deep in some places, as previously reported by Nordhaus et al. (2009).

Ucides cordatus has presented seasonal reproduction (WUNDERLICH et al., 2008), confirmed in this study. According to those authors, despite the latitudinal variation due to the influence of temperature, photoperiod and precipitation, the reproductive season of this species lasts for 5-6 months, usually from November to May, which is consistent with the results of this study.

The significant predominance of females in the population of Vitória Bay is probably related to the increased intensity of the harvesting of males, as already reported by other authors, mainly in the Northeastern Region (COSTA, 1979; BOTELHO et al., 1999; IVO et al., 1999). Since males have a higher rate of growth in size and weight (PINHEIRO et al., 2005) they are the main target of capture by the crab pickers (GÓES et al., 2000). This assertion is supported by the distribution of individuals by size class, in which a significant predominance of females between $50-75 \mathrm{~mm}$ may be related to this fishing effort aimed specifically at males. Similar results were obtained by Diele (2000) in the Caeté Estuary (PA) and related to catch pressure mainly in the areas most easily accessible to crab catchers. However, differences in sex ratio may be due to different rates of mortality/growth between sexes (WENNER, 1972), by association with a certain phase of the reproductive cycle (COSTA, 1979) or due to the flood level and arboreal composition of the mangrove area studied (WUNDERLICH; PINHEIRO, in preparation). The sex ratio datum obtained by Alves and Nishida (2004) from a Permanent Protect Area of the Mamanguape River (PB) was $1.85 \mathrm{M}: 1 \mathrm{~F}$, indicating a greater prevalence of males in an environment with little anthropic influence.

The maximum crab sizes $(\mathrm{CW})$ registered in the present study (males, $80.3 \mathrm{~mm}$; females, $77.4 \mathrm{~mm}$ ) are a little inferior to those found in the Northeastern (86 and 81mm, respectively) (CASTRO, 1986; VASCONCELOS et al., 1999) and Southern Brazilian Regions (96 and $77 \mathrm{~mm}$ ) (BRANCO, 1993). In the mangrove forests of the Vitória Bay the crabs presented an isometric wet weight growth pattern for males and females, revealing a tendency very similar to that obtained by Pinheiro and Fiscarelli (2009), despite the negative alometry verified by these last authors with regard to females. The reduction of the crab size, weight and abundance in various mangrove areas in Brazil reveals the great pressure to which the uçá-crab population has been subject. This fact is also a matter of concern as regards Vitória Bay, where a large number of crab catchers are active, a situation which may lead to the collapse of the crab fishery in the near future. It is therefore to be hoped that the results obtained by this study may strengthen the perceived need for the planning and management of the harvesting of this species.

\section{REFERENCES}

ALCÂNTARA-FILHO, P. Contribuição para o conhecimento da biologia e ecologia do caranguejo-uçá - Ucides cordatus (Linnaeus, 1763) (Crustacea, Decapoda, Brachyura) no manguezal do Rio Ceará (Brasil). Arq. Ciênc. Mar., v. 18, n. 1/2, p. 1-41, 1978.

ALVES, R. R. N.; NISHIDA, A. K. Population structure of the mangrove crab Ucides cordatus (Crustacea: Decapoda; Brachyura) in the estuary of the Mamanguape River, Northeast Brazil. Trop. Oceanogr., v. 32, n. 1, p. 23-37, 2004.

ARAÚJO, A. R. R. Fishery statistics and commercialization of the mangrove crab, Ucides cordatus (L.), in Bragança - Pará - Brazil. 2006. 176 p. Doctoral thesis - University of Bremen, Bremen (Germany). 
ARAÚJO, M. S. L. C.; CALADO, T. C. S. Bioecologia do Caranguejo-Uçá Ucides cordatus (Linnaeus) no Complexo Estuarino Lagunar Mundáu/Manguaba (CELMM), Alagoas, Brasil. Rev. Gestão cost. integr., v. 8, n. 2, p. 169-181, 2008.

BLANKENSTEYN, A.; FILHO, C. D.; FREIRE, A. S Distribuição de estoques pesqueiros e conteúdo protéico do caranguejo do mangue Ucides cordatus (L., 1763) (Brachyura, Ocypodidae) nos manguezais da Baía das Laranjeiras e adjacências, Paraná, Brasil. Arq. Biol. Tecnol., v. 40, n. 2, p. 331-349, 1997.

BOTELHO, E. R. O.; DIAS, A. F.; IVO, C. T. C. Estudo sobre a biologia do caranguejo-uçá, Ucides cordatus cordatus (Linnaeus, 1763), capturado nos estuários dos rios formoso (Rio Formoso) e Ilhetas (Tamandaré), no Estado de Pernambuco. Bolm técn.-cient. CEPENE, v. 7, n. 1, p. 117-145, 1999

BRANCO, J. O. 1993. Aspectos bioecológicos do caranguejo Ucides cordatus (Linnaeus, 1763) (Crustacea, Decapoda) do manguezal do Itacorubi, Santa Catarina, BR. Arq. Biol. Tecnol., v. 36, n. 1, p. 133-148, 1993.

BROWN, A. C.; MCLACHLAN A. M. C. Ecology of sandy shores. Amsterdam: Elsevier, 1994. p. 327.

CARMO, T. M. S. Os manguezais ao norte da Baía de Vitória, ES. In: SIMPÓSIO SOBRE ECOSSISTEMAS DA COSTA SUL E SUDESTE BRASILEIRA. Síntese dos conhecimentos. Cananéia, SP. ACIESP, 1987. v. 1, p. $173-193$.

CARMO, T. M. S.; BRITO-ABAURRE, M. G.; SENNAMELO, R. M.; ZANOTTI-XAVIER, S.; COSTA, M. B.; HORTA, M. M. M. Os manguezais da Baía Norte de Vitória, Espírito Santo: um ecossistema ameaçado. Rev. Bras. Biol., v. 55, n. 4, p. 801-808, 1995.

CASTILHO-WESTPHAL, G. G.; OSTRENSKY, A.; PIE, M. R.; BOEGER, W. A. Estado da arte das pesquisas com o caranguejo-uçá, Ucides cordatus. Archvs Veterin. Sci., v. 13, n. 2, p. 151-166, 2008.

CASTRO, A. C. L. Aspectos bio-ecológicos do caranguejouçá, Ucides cordatus (Linnaeus 1763), no estuário do rio dos Cachorros e estreito do Coqueiro, São Luís, MA. Bol. Lab. Hidrobiol, v. 7, n. 1, p. 7-26, 1986.

CHRISTOFOLETTI, R. A. Ecologia trófica do caranguejouçá, Ucides cordatus (Linnaeus, 1763) (Crustacea, Ocypodidae) e o fluxo de nutrientes em bosques de mangue, na região de Iguape (SP). 2005. 139 p. Tese (Doutorado) - Universidade Estadual Paulista, Faculdade de Ciências Agrárias e Veterinárias, Jaboticabal, SP, 2005.

COSTA, R. S. Bioecologia do caranguejo-uçá Ucides cordatus (Linnaeus, 1763) (Crustacea, Decapoda) do nordeste brasileiro. Bol. Cear. Agron., v. 20, n. 1, p. 174, 1979.

DALABONA, G.; LOYOLA-E-SILVA, J.; PINHEIRO, M.A.A. Size at morphological maturity of Ucides cordatus (Linnaeus, 1763) (Brachyura, Ocypodidae) in the Laranjeiras Bay, Southern Brazil. Brazil. Archs Biol. Technol., v. 48, n. 1, p. 139-145, 2005.

DIELE, K. (Decapoda: Brachyura) in the Caete' Estuary, North Brazil Life history and population structure of the exploited mangrove crab Ucides cordatus cordatus (Linnaeus, 1763), 2000. 116 p. Doctoral thesis - University of Bremen, Bremen, 2000.
DIELE, K.; KOCH, V.; SAINT-PAUL, U. Population structure, catch composition and CPUE of the artisanally harvested mangrove crab Ucides cordatus (Ocypodidae) in the Caeté estuary, North Brazil: Indications for overfishing? Aquat. Living Resour., v. 18, p. 169-178, 2005.

FERNANDES, M. E. B.; CARVALHO, M. L. Bioecologia de Ucides cordatus Linnaeus, 1763 (Decapoda: Brachyura) na costa do Estado do Amapá. Bol. Lab. Hidrobiol., v. 20, p. 15-22, 2007.

GOES, P.; SAMPAIO, F. D. F.; CARMO, T. M. S.; LEAL, M. S.; TOSO, G. C. Comportamento e período reprodutivo do caranguejo Ucides cordatus (Linnaeus, 1763), no manguezal da Baía de Vitória, Vitória, ES. In: SIMPÓSIO DE ECOSSISTEMAS BRASILEIROS: Conservação, 2000. São Paulo, ACIESP, 2000. v. 2, p 335-348.

HATTORI, G. Y. Densidade Populacional do CaranguejoUçá, Ucides cordatus (Linnaues, 1763) (Crustacea: Brachyura: Ocypodidae) em Iguape, SP. 2006. 143p. Tese (Doutorado) - Universidade Estadual Paulista, Faculdade de Ciências Agrárias e Veterinárias, Jaboticabal, SP, 2006. .

IBAMA - Instituto Brasileiro do Meio Ambiente e dos Recursos Naturais Renováveis. Lagosta, CaranguejoUçá e Camarão do Nordeste. Brasília DF: 1994. Coleção Meio Ambiente. Série Estudos - Pesca, v. 10, $190 \mathrm{p}$.

IBAMA - Instituto Brasileiro do Meio Ambiente e dos Recursos Naturais Renováveis. Portaria $\mathbf{n}^{\circ}$ 52, de 30 de setembro de 2003 - Defeso pesqueiro do CaranguejoUçá (Ucides cordatus).

IBGE - Instituto Brasileiro de Geografia e Estatística.. Estimativas preliminares para $1^{\circ}$ de julho de 2009. D.O.U., Brasilia ,DF 14 de agosto de 2009.

IVO, C. T. C.; DIAS, A. F.; MOTA, R. I. Estudo sobre a biologia do caranguejo-uçá, Ucides cordatus cordatus (Linnaeus, 1763), capturado no delta do Rio Parnaíba, estado do Piauí. Bolm técn.-científ. CEPENE, v. 7, n. 1, p. 53-84, 1999.

IVO, C. T. C.; DIAS, A. F.; BOTELHO, E. R. O.; MOTA, R. I.; VASCONCELOS, J. A.; VASCONCELOS, E. M. S. Caracterização das populações de caranguejo-uçá, Ucides cordatus cordatus (Linnaeus, 1763), capturadas em estuários do nordeste do Brasil. Bolm técn.-cient. CEPENE, v. 8, n. 1, p. 7-42, 2000.

KRISTENSEN, E. Mangrove crabs as ecosystem engineers; with emphasis on sediment processes. J. Sea Res., v. 59, p. 30-43, 2008 .

LEGAT, J. F. A.; PUCHNICK, A. L. Sustentabilidade da pesca do caranguejo-uçá, Ucides cordatus, nos estados do Piauí e do Maranhão: Uma visão da cadeia produtiva do caranguejo a partir de fóruns participativos de discussão. Teresina: Embrapa, 2003.Relatório técnico.

MACIA, A.; QUINCARDETE, I.; PAULA, J. A comparison of alternative methods for estimating population density of the fiddler crab Uca annulipes at Saco Mangrove, Inhaca Island (Mozambique). Hidrobiol., v. 449, p. 213219, 2001.

MACINTOSH, D. J. The ecology and physiology of decapods of mangrove swamps. Symp. Zool. Soc. Lond., v. 59, p. 315-341, 1988. 
MELO, G. A. S. Manual de identificação dos Brachyura (caranguejos e siris) do litoral brasileiro. São Paulo: Plêide/FAPESP, 1996. 604 p.

MMA - Ministério do Meio Ambiente. Instrução Normativa $\mathbf{n}^{\circ}$ 5, de 21 de maio de 2004 - Anexo II: Lista Nacional das espécies de invertebrados aquáticos e peixes sobreexplotadas ou ameaçadas de sobreexplotação. 2004

NASCIMENTO, S. A. Biologia do caranguejo-uçá (Ucides cordatus). Relat. téc. Adema: Aracaju, v. 1, p. 1- 48, 1993.

NASCIMENTO, S. A.; COSTA, R. S. Estudo bioecológico do caranguejo-uçá Ucides cordatus (Linnaeus, 1763) e do manguezal da ilha do Paiva - São Cristovão - Estado de Sergipe - Brasil. In: Encontro Brasileiro de Gerenciamento Costeiro, 3. Fortaleza, Anais. p 313 323,1983

NORDHAUS, I.; WOLFF, M. Feeding ecology of the mangrove crab Ucides cordatus (Ocypodidae): food choice, food quality and assimilation efficiency. Mar. Biol., v. 151, p. 1665-1681, 2007.

NORDHAUS, I.; WOLFF, M.; DIELE, K. Litter processing and population food intake of the mangrove crab Ucides cordatus in a high intertidal forest in northern Brazil. Estuar. coast. Shelf Sci., v. 67, p. 239-250, 2006.

NORDHAUS, I; DIELE, K.; WOLFF, M. Activity patterns, feeding and burrowing behaviour of the crab Ucides cordatus (Ucididae) in a high intertidal mangrove forest in North Brazil. J. expl. mar. Biol. Ecol., v. 374, p. 104-112, 2009.

OLIVEIRA, D. A. F. Distribuição espacial do Caranguejo-Uçá, Ucides cordatus (Linnaeus, 1763) (Crustacea, Brachyura, Ocypodidae). 2005. 57p. Monografia (Graduação) - Universidade Estadual Paulista, Campus Experimental do Litoral Paulista, São Vicente, SP, 2005

PENHA-LOPES, G.; BARTOLINI, F.; LIMBU, S.; CANNICI, S.; KRISTENSEN, E.; PAULA, J. Are fiddler crabs potentially useful ecosystem engineers in mangrove wastewater wetlands? Mar. Pollut. Bull., v. 58, p. 1694-1703, 2009.

PINHEIRO, M. A. A. Biologia do Caranguejo-Uçá, Ucides cordatus (Linnaeus, 1763) (Crustacea, Decapoda, Brachyura), no Litoral Sul do Estado de São Paulo. 2004. 203p. Relatório Científico (Projeto Uçá I FAPESP \# 1998/06055-0) - Universidade Estadual Paulista, Faculdade de Ciências Agrárias e Veterinárias, Jaboticabal, SP, 2004

PINHEIRO, M. A. A.; FISCARELLI, A. G. Length-weight relationship of the carapace and condition factor of the mangrove crab Ucides cordatus (Linnaeus, 1763) (Crustacea, Brachyura, Ucididae). Braz. Archs Biol. Technol., v. 52, n. 2, p. 397-406, 2009.

PINHEIRO, M. A. A.; FISCARELLI, A. G. Manual de apoio à fiscalização do caranguejo-uçá (Ucides cordatus). Itajaí, SC: IBAMA/CEPSUL, 2001. 60 p.

PINHEIRO, M. A. A.; FISCARELLI, A. G.; HATTORI, G. Y. Growth of the mangrove crab Ucides cordatus (Brachyura, Ocypodidae). J. Crust. Biol, v.25, n.2, p.293-301, 2005.

PINHEIRO, M. A. A.; HATTORI, G. Y. Relative growth of the mangrove crab Ucides cordatus (Crustacea, Brachyura, Ocypodidae) at Iguape (SP), Brazil. Braz.
Archives of Biology and Technology, v. 49, n. 5, p. 813823, 2006.

PRATOOMCHAT, B.; SAWANGWONG, P.; PAKKONG, P.; MACHADO, J. Organic and inorganic compound variations in haemolymph, epidermal tissue and cuticle over the molt cycle in Scylla serrata (Decapoda). Comp. Biochem. Physiol., Part A, v. 131, p. 243-255, 2002.

REBELO-MOCHEL, F. C. Metodologia para o estudo da endofauna de manguezais (macrobentos). In: SCHAEFFER-NOVELLI, Y.; CINTRÓN, G. Guia para estudo de areas de manguezal: Estrutura, função e flora. São Paulo: Caribbean Ecological Research., v. 3, p. 1-25, 1986.

RODRIGUES, A. M. T.; BRANCO, E. J.; SACCARDO, S. A.; BLANKENSTEYN, A. A exploração do caranguejo Ucides cordatus (Decapoda: Ocypodidae) e o processo de gestão participativa para normatização da atividade na região sudeste-sul do Brasil. Bolm Inst. Pesca, São Paulo, v. 26, n. 1, p. 63-78, 2000.

SANTOS, C. M. H.; PINHEIRO, M. A. A.; HATTORI, G. Y. Orientation and external morphology of burrows of the mangrove crab Ucides cordatus (Crustacea, Brachyura, Ucididae). J. mar. Biol. Ass. U. K., v. 89, n. 6, p. 1117-1123, 2009.

VALE, C. C. Homens e caranguejos: uma contribuição geográfica ao estudo dos manguezais da Baía de Vitória (ES) como fonte de alimento. In: SIMPÓSIO DE ECOSSISTEMAS DA COSTA BRASILEIRA: Subsídios a um gerenciamento ambiental. São Paulo, ACIESP, 1994. v. 1, p. 269-273.

VASCONCELOS, M. S.; VASCONCELOS, J. A.; IVO, C. T. C. Estudo sobre a biologia do caranguejo-uçá Ucides cordatus cordatus (Linnaeus, 1763), capturado no Estuário do Rio Curimatau (Canguaretama) no Estado do Rio Grande do Norte. Bol. técn.- cient. CEPENE, v. 7, p. 85-116, 1999.

VAZZOLER, A. E. A. M. Biologia da reprodução de peixes teleósteos: teoria e prática. Maringá, PR: Ed. EDUEM, 1996. $169 \mathrm{p}$.

WARNER, G. F. The occurrence and distribution of crabs in Jamaican mangrove swamp. J. Anim. Ecol., v. 38, p. 379-389, 1969.

WENNER, A. M. Sex ratio as a function of size in marine Crustacea. Am. Naturalist, v. 106, n. 949, p. 321-350, 1972.

WHEATLY, M. G.; ZANOTTO, F. P.; HUBBARD, M. G. Calcium homeostasis in crustaceans: Subcellular $\mathrm{Ca}$ dynamics. Com. Biochem. Physiol. B, v. 132, n. 1, p. 163-178. 2002.

WOLFF, M.; KOCHA, V.; ISAAC, V. A trophic flow model of the Caeté Mangrove Estuary (North Brazil) with considerations for the sustainable use of its resources. Estuar. Coast. Shelf Sci., v. 50, p. 789-803, 2000.

WUNDERLICH, A. C. \& PINHEIRO, M. A. A. Sex ratio of the crab Ucides cordatus (Linnaeus, 1763) from three subtropical mangrove forests. Hidrobiol., in preparation.

WUNDERLICH, A. C.; PINHEIRO, M. A. A.; RODRIGUES, A. M. T. Biologia do Caranguejo-Uçá, Ucides cordatus (Linnaeus) (Crustacea, Decapoda, Brachyura), na Baía da Babitonga, Santa Catarina, Brasil. Rev. Bras. Zool.,, v. 25, n. 2, p. 188-198, 2008. 
ZAR, J. H. Biostatistical analysis. New Jersey: PrenticeHall, 1999. $663 \mathrm{p}$.

ZIEGLER, A. X-ray microprobe analysis of epithelial calcium transport. Cell Calcium, v. 31, n. 6, p. 307-321, 2002 .

(Manuscript received 18 September 2009; revised

21 January 2010; accepted 10 March 2010) 